Jurnal ELTIKOM, Vol. 1 No.2, Desember 2017, Hal 84-93

ISSN 2598-3245 (Print), ISSN 2598-3288 (Online)

Tersedia Online di http://eltikom.poliban.ac.id

\title{
TEKNIK KONSERVASI ENERGI PADA POMPA SUBMERSIBLE DENGAN MENGGUNAKAN VARIABLE FREQUENCY DRIVE
}

\author{
Sofyar \\ Departemen Teknologi Listrik Akademi Teknologi Pembangunan Nasional Banjarbaru \\ e-mail: h.sofyar@gmail.com
}

\begin{abstract}
Energy conservation is beneficial not only to reduce consumption and the cost of energy consumption, but also to give a better impact on the environment. In this study a simulation model is created which is a reflection of the relationship con-dition between variable frequency drive (VFD), induction motor and centrifugal pump. By creating a simulation model will be able to know the potential savings that will be provided if the variable frequency drive is used.
\end{abstract}

Keywords: Energy conservation, submersible pumps, variable frequency drives

\section{ABSTRAK}

Konservasi energi bermanfaat tidak hanya untuk menekan konsomsi energi dan biaya konsumsi energi, namun juga memberikan dampak yang lebih baik terhadap lingkungan. Pada penelitian ini dibuat suatu model simulasi yang merupa-kan refleksi dari kondisi hubungan antara variable frequency drive (VFD), motor induksi dan pompa sentrifugal. Dengan membuat model simulasi akan dapat diketahui potensi penghematan yang akan diberikan sekiranya variable frequency drive tersebut digunakan.

Kata Kunci: Konservasi energi, pompa submersible, variable frequency drive

\section{PENDAHULUAN}

$\mathrm{S}$ ejak mulai berkurangnya ketersediaan sumber energi konvensional atau bahan bakar fosil, menuntut kita bekerja keras untuk mengembangkan, memperbaiki dan memperbaharui dari sumber energi terbarukan, melalui proteksi, dan konservasi dari keberadaan sumber energi konvensional. Konservasi energi juga membantu memperbaiki lingkungan, karena dengan konservasi energi berarti mengurangi penggunaan bahan bakar fosil dan ini berarti mengurangi emisi gas karbon dioksida.

Suatu bagian terbesar dari daya listrik pada sebuah pembangkit dikonsumsi oleh penggerak listrik. Jumlah yang signifikan dari energi listrik dapat dihemat dengan menggunakan penggerak listrik (motor listrik) yang efisien. Variable frequency drive (VFD) adalah satu dari beberapa drive efisiensi energi yang dikenal. Variable frequency drive memiliki kemampuan untuk mengontrol kecepatan motor induksi, yang mana merupakan motor yang paling banyak digunakan dalam industri. Variable frequency drive adalah suatu sistem yang digunakan untuk mengontrol kecepatan rotasi dari motor arus bolakbalik dengan mengontrol frekuensi daya listrik yang disuplai ke motor.

Pada sistem pemompaan, pompa submersible termasuk dalam pompa sentrifugal yang merupakan salah satu peralatan yang paling sederhana dalam berbagai proses pabrik. Pada pompa submersible, motor induksi merupakan bagian atau komponen utama yang berfungsi sebagai mesin penggerak, memutar pompa untuk memindahkan cairan (air) dari satu tempat ke tempat yang lain. Sebagaimana diketahui, air merupakan elemen penting bagi kehidupan dan tubuh manusia. Hampir setiap kegiatan manusia selalu berhubungan dengan penggunaan air. Walaupun air tesedia berlimpah di alam namun tidak semua air yang ada bisa dimanfaatkan. Dalam operasional suatu perusahaan daerah air minum (PDAM), penyediaan dan pelayanan air bersih kepada konsumen digunakan motor listrik untuk menggerakan pompa. 


\section{LANDASAN TEORI}

Konservasi energi bermanfaat bukan hanya untuk menekan konsumsi dan biaya konsumsi energi, namun juga memberikan dampak yang lebih baik terhadap lingkungan. Sebagai dimaklumi, sumber utama pemanasan global yang dikhawatirkan masyarakat planet bumi kini adalah pembakaran bahan bakar fosil, atau aktivitas manusia yang berkaitan dengan penggunaan energi [1]. Berdasarkan arah kebijakan energi nasional, konservasi energi merupakan salah satu kebijakan energi yang sejalan dengan upaya mitigasi perubahan iklim yaitu mengurangi emisi gas rumah kaca [2].

\section{A. Variable Frequency Drive (VFD)}

Variable frequency drive adalah peralatan yang digunakan untuk memvariasikan kecepatan dari motor induksi 3-phasa. Dia bekerja mengatur frekuensi dari suplai daya ke motor [3]. Keluaran sistem dapat dikontrol dengan mengatur kecepatan motor dengan menggunakan variable frequency drive (VFD). Pada kontrol kecepatan dari motor induksi AC, beberapa metode kontrol kecepatan yang digunakan adalah: kontrol kecepatan dengan mengubah resistansi rotor, kontrol kecepatan dengan mengubah jumlah kutub, kontrol kecepatan dengan menubah tegangan stator, dan kontrol frekuensi suplai atau kontrol v/f [4].

Kontrol motor dengan menggunakan variable frequency drive juga telah digunakan pada banyak pengairan dalam usaha untuk penghematan energi [5]. Suatu pemahaman yang terbaik dari variable frequency drive akan mendorong pada perbaikan aplikasi dan pemilihan peralatan dan sistem heating, ventilation, and air conditioning.

Sebagian besar produk variable frequency drive sekarang mempunyai empat bagian fundamental, yaitu: input rectifier atau converter, DC bus, output stack atau VFD, dan controller [6].

Ada bermacam tipe dari inverter, dan mereka diklasifikasikan berdasarkan jumlah dari phasa, peralatan semikonduktor yang digunakan, prinsip komutasi, dan bentuk gelombang output [7].

Variable frequency drive sudah biasa digunakan untuk kecepatan pompa yang bervariasi. Kombinasi pompa-VFD menawarkan tindakan konservasi energi yang menarik untuk kasus dimana dibutuhkan aliran yang bervariasi pada sistem distribusi fluida [8].

\section{B. Pulse Width Modulation (PWM)}

Modulasi lebar pulsa atau pulse width modulation (PWM) secara umum adalah sebuah cara memanipulasi lebar sinyal yang dinyatakan dengan pulsa dalam suatu perioda, untuk mendapatkan tegangan rata-rata yang berbeda [9].

Dengan menggunakan PWM kita dapat mengatur kecepatan yang diinginkan dengan mudah. Teknik PWM untuk mengatur kecepatan motor dengan cara merubah-ubah besarnya duty cycle pulsa. Pulsa yang berubah-ubah duty cycle-nya inilah yang menentukan kecepatan motor. Besarnya amplitudo dan frekuensi pulsa adalah tetap, sedangkan besarnya duty cycle maka semakin cepat pula kecepatan motor, dan sebaliknya semakin kecil duty cycle maka semakin pelan pula kecepatan motor.

Strategi modern untuk mengontrol keluaran AC dari beberapa peralatan konverter elektronik daya adalah teknik yang dikenal dengan modulasi lebar pulsa (PWM). Berdasarkan prinsipnya, semua skema modulasi bertujuan membuat deretan pulsa pengsaklaran yang memiliki yang memiliki volt-second average fundamental yang sama sebagai suatu target bentuk gelombang referensi pada beberapa saat [7].

\section{Motor Induksi}

Penggunaan motor induksi 3-phasa untuk diaplikasi mesin-mesin telah banyak digunakan pada dunia industri karena mempunyai konstuksi yang sederhana sehingga mudah dalam perawatannya. Kelemahan utama motor induksi 3-phasa adalah arus starting yang cukup tinggi dan torsi awal yang rendah [10].

Prinsip kerja motor induksi adalah sebagai berikut: apabila sumber tegangan 3-phasa dipasang pada kumparan stator akan timbul medan putar dengan kecepatan $\mathrm{n}_{\mathrm{s}}$. Kemudian medan putar stator tersebut akan memotong batang konduktor rotor, akibatnya pada kumparan rotor timbul tegangan induksi $\mathrm{E}_{2 \mathrm{~s}}$. Karena kumparan rotor merupakan rangkaian tertutup maka tegangan induksi akan menghasilkan arus (I). Adanya arus di dalam medan magnet akan menimbulkan gaya (F) pada rotor. Bila kopel mula yang dihasilkan oleh gaya (F) pada rotor cukup besar untuk memikul kopel beban, rotor akan berputar searah dengan medan putar stator [11]. 
Motor induksi 3-phasa bekerja sebagai pengkonversi energi listrik ke energi mekanik yang memberikan torsi elektromagnetik untuk pompa sentrifugal [12].

\section{Pompa Sentrifugal}

Sistem pemompaan bertanggung jawab terhadap hampir $20 \%$ kebutuhan listrik dunia dan penggunaan energi dalam operasi pabrik industri tertentu 25-50\% [14].

Pompa sentrifugal termasuk jenis pompa dinamik, dimana impeler yang berputar mengubah energi kinetik menjadi tekanan atau kecepatan yang diperlukan untuk memompa fluida. Pompa sentrifugal merupakan pompa yang sangat umum digunakan untuk pompa air dalam berbagai penggunaan industri, dan pompa sentrifugal merupakan salah satu peralatan yang paling sederhana dalam berbagai proses pabrik. Biasanya lebih dari 75\% pompa yang dipasang di sebuah industri adalah pompa sentrifugal [14].

Pompa Submersible atau pompa benam, disebut juga electric submersible pump (ESP) adalah pompa yang dioperasikan di dalam air dan akan mengalami kerusakan jika dioperasikan dalam keadaan tidak terdapat air terus-menerus. Pompa submersible termasuk pompa tipe sentrifugal, dimana energi kinetis (kecepatan) cairan diubah menjadi energi potensial (dinamis) melalui suatu impeler yang berputar dalam casing.

Pada perusahaan daerah air minum (PDAM), pompa submersible digunakan sebagai bagian dari peralatan untuk memproduksi air siap konsumsi. Pompa submersible digunakan untuk mengambil air baku dari sumur dalam, selanjutnya dilakukan pengolahan di instansi pengolahan air.

\section{E. Formulasi}

Formulasi yang digunakan pada penelitian ini, adalah:

- Kecepatan sinkron dari motor induksi [9][12-13]

$$
\begin{aligned}
& \mathrm{N}_{\mathrm{s}}=\frac{120 f}{\mathrm{p}} \\
& \text { dengan: } \\
& f=\text { frekuensi } \\
& \mathrm{p}=\text { jumlah kutub }
\end{aligned}
$$

Kecepatan sinkron berbanding langsung dengan frekuensi suplai. Sehingga dengan mengubah frekuensi, kecepatan sinkron dan kecepatan motor dapat dikontrol dibawah dan diatas kecepatan beban penuh normalnya.

- Untuk pompa sentrifugal [6][8][12][14]

Parameter kinerja pompa (debit alir, head, daya) akan berubah dengan bervariasinya kecepatan putar. Oleh karena itu, untuk mengendalikan kecepatan yang aman pada kecepatan yang berbeda maka penting untuk mengerti hubungan antara keduanya.

Untuk debit aliran atau liquid flow (Q) berbanding lurus dengan kecepatan putar (N). Sedangkan untuk head $(\mathrm{H})$ berbanding lurus dengan kuadrat kecepatan putar, dan untuk daya $(\mathrm{P})$ berbanding lurus dengan kubik kecepatan putar.

$$
\begin{gathered}
\frac{\mathrm{Q} 1}{\mathrm{Q} 2}=\frac{\mathrm{N} 1}{\mathrm{~N} 2} \\
\frac{\mathrm{H} 1}{\mathrm{H} 2}=\left(\frac{\mathrm{N} 1}{\mathrm{~N} 2}\right)^{2} \\
\frac{\mathrm{P} 1}{\mathrm{P} 2}=\left(\frac{\mathrm{N} 1}{\mathrm{~N} 2}\right)^{3}
\end{gathered}
$$

Daya yang dibutuhkan pompa secara teoritis atau daya hidrolik adalah daya dalam hp (horse power) cairan yang dikirimkan oleh pompa ditentukan dengan: 


$$
\mathrm{P}_{\text {teo }}=\mathrm{Q} \times \mathrm{H} \times \rho \times \mathrm{g} / 1000
$$

dengan:

$\begin{array}{ll}\mathrm{P}_{\text {teo }} \text { dalam horse power } & (\mathrm{hp}) \\ \mathrm{Q}=\text { debit aliran } & \left(\mathrm{m}^{3} / \text { detik }\right) \\ \mathrm{H}=\text { head } & (\mathrm{m}) \\ \rho=\text { massa jenis fluida } & \left(\mathrm{kg} / \mathrm{m}^{3}\right) \\ \mathrm{g}=\text { percepatan grafitasi } & \left(\mathrm{m} / \text { detik }^{2}\right)\end{array}$

Daya batang torak pompa atau $\mathrm{P}_{\text {shaft }}$ adalah daya dalam hp yang dikirimkan ke batang torak pompa dihitung dengan:

$$
P_{\text {shaft }}=\frac{P_{\text {teo }}}{\eta_{p}}
$$

dengan:

$\eta_{\mathrm{p}}=$ efisiensi pompa

- Penghematan energi [4]

Potensi penghematan energi dengan pemasangan variable frequency drive (VFD) dapat diketahui dengan menghitung biaya operasional dari motor induksi yang menggerakan pompa sentrifugal. Dengan mempertimbangkan daya motor induksi $(\mathrm{kW})$ operasi pompa pada kecepatan penuh selama 365 hari dalam setahun, dan 24 jam setiap harinya. Biaya operasional dapat dihitung dengan persamaan:

$$
\begin{aligned}
& \text { Biaya = daya }(\mathrm{kW}) \times \text { waktu operasi }(\mathrm{Jam}) \times \text { biaya energi/kWh } \\
& \text { Biaya dihemat = biaya operasional } \text { Kecepatan } 100 \%^{-}\left(\sum \text { biaya operasional } \text { (\%waktu operasi penuh) }\right)
\end{aligned}
$$

Atau dengan persamaan:

Konsumsi energi rata-rata per hari dengan menggunakan VFD (E1)

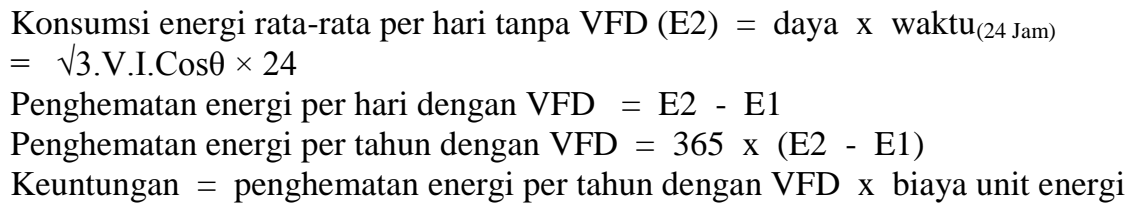

\section{METODOLOGI}

\section{A. Jalannya Penelitian}

Langkah pertama yaitu, mengumpulkan semua data-data yang dibutuhkan di lapangan, mengamati langsung ke lokasi, dan melakukan Tanyajawab di lapangan. Selanjutnya mengolah data-data yang diperoleh tersebut untuk dianalisis.

Langkah kedua yaitu membuat rangkaian variable frequency drive (VFD) dengan mengacu pada journal dari peneliti-peneliti sebelumnya dan literatur lain yang berhubungan dengan penelitian, dan menggunakan program simulasi. Dengan menggunakan parameter-parameter dari motor, pompa dan data yang diperoleh di lapangan, dimasukan ke dalam simulasi rangkaian VFD, dan selanjutnya dianalisis hasil keluarannya.

Langkah ketiga yaitu, menghitung besarnya daya yang dihemat dari penggunaan variable frequency drive (VFD).

Langkah keempat, membandingkan hasil dari langkah ketiga dengan pemakaian daya sebelum menggunakan VFD. Menganalisis beberapa besaran daya yang dihemat dan signifikankah perbedaannya, kemudian membuat kesimpulan.

\section{B. Diagram Alir Penelitian}

Diagram alir atau flowchat penelitian selengkapnya dapat dilihat pada gambar 1. 


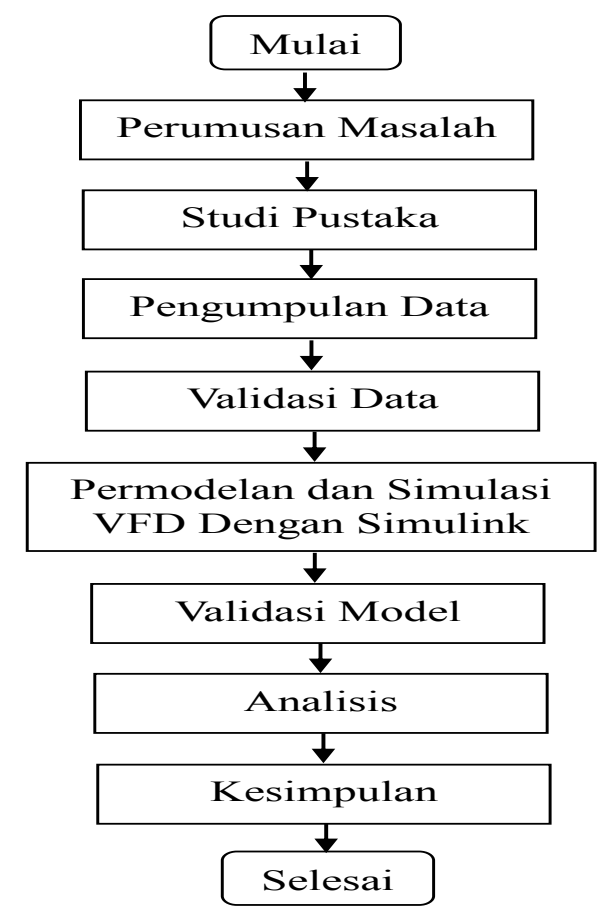

Gambar 1. Diagram alir penelitian

\section{PERHITUNGAN DAN HASIL}

\section{A. Instalasi Pengolahan Air (IPA)}

Pada perusahaan daerah air minum (PDAM), air baku yang merupakan bahan utama dalam proses produksi diambil langsung dari sumber mata air dan sumur dangkal maupun sumur dalam. Selanjutnya air baku tersebut diolah sedemikian rupa untuk menghasilkan air yang siap konsumsi. Setiap tahap pengolahan yang dilakukan mempunyai fungsi dan tujuan yang berbeda. Tahap-tahap pengolahan air inilah yang disebut dengan instalasi pengolahan air (IPA).

Pada penelitian ini, lokasinya dipilih pada Perusahaan Daerah Air Minum (PDAM) Tirtamarta Yogyakarta, dimana pada PDAM tersebut untuk air bersih yang ditampung di reservoir disalurkan ke konsumen menggunakan motor listrik dan gaya grafitasi bumi. Untuk IPA Pengok dan IPA Kota Gede distribusinya menggunakan motor listrik. Selanjutnya pada penelitian ini dibatasi hanya pada IPA Pengok yang dianalisis.

Spesifikasi pompa yang digunakan pada IPA Pengok diperlihatkan pada tabel 1. Sedangkan untuk spesifikasi motor induksinya diperlihatkan pada tabel 2.

\section{B. Desain Model Simulasi Pemrograman}

Desain model simulasi pemrograman ini merupakan refleksi dari kondisi hubungan antara variable frequency drive (VFD), motor induksi dan pompa sentrifugal dalam mendistribusikan air bersih ke pelanggan. Selanjutnya dibuat juga model rangkaian tanpa menggunakan variable frequency drive (VFD) dan membandingkannya dengan yang menggunakan VFD.

Untuk analisisnya, model simulasi pemrograman ini terdiri dari blok sumber tegangan 3 phasa, blok variablefrequency drive, blok motor induksi, dan blok pompa sentrifugal; menggunakan model yang disediakan pada Simulink.

TABEL 1

SPESIFIKASI POMPA SUBMERSIBLE SP 77 DAN SP 30

\begin{tabular}{|l|l|l|l|}
\hline No & \multicolumn{1}{|c|}{ Spesifikasi } & \multicolumn{1}{|c|}{$\begin{array}{c}\text { Keterangan } \\
(\text { Pengok 1) }\end{array}$} & $\begin{array}{c}\text { Keterangan } \\
(\text { Pengok 2) }\end{array}$ \\
\hline 1. & Merk & Groundfos & Groundfos \\
\hline 2. & Tipe & SP 77-3 & SP 30-5 \\
\hline 3. & Kapasitas Q $\left(\mathrm{m}^{3} / \mathrm{H}\right)$ & 100 & 40 \\
\hline 4. & Tekanan $\mathrm{p}(\mathrm{k} \mathrm{Pa})$ & $>250 \mathrm{p}<600$ & $>250 \mathrm{p}<550$ \\
\hline
\end{tabular}




\begin{tabular}{|l|l|l|l|}
\hline 5. & Head H $(\mathrm{m})$ & $>22 \mathrm{H}<60$ & $>22 \mathrm{H}<59$ \\
\hline 6. & Efisiensi $(\%)$ & 78 & 75 \\
\hline
\end{tabular}

TABEL 2

SPESIFIKASI MOTOR INDUKSI MS 6000

\begin{tabular}{|l|l|l|l|}
\hline No & \multicolumn{1}{|c|}{ Spesifikasi } & \multicolumn{1}{|c|}{$\begin{array}{c}\text { Keterangan } \\
\text { (Pengok 1) }\end{array}$} & $\begin{array}{c}\text { Keterangan } \\
\text { (Pengok 2) }\end{array}$ \\
\hline 1. & Merk & Grundfos & Grundfos \\
\hline 2. & Tipe & MS 6000 & MS 6000 \\
\hline 3. & Frequency $(\mathrm{Hz})$ & 50 & 50 \\
\hline 4. & Pole & 2 & 2 \\
\hline 5. & Output $(\mathrm{kW})$ & 11 & 5,5 \\
\hline 6. & Output $(\mathrm{HP})$ & 15 & 15 \\
\hline 7. & Speed $(\mathrm{rpm})$ & 2870 & 2870 \\
\hline 8. & FLC 380V $(\mathrm{A})$ & 24,8 & 13,6 \\
\hline 9. & Motor Efficiency & 82,5 & 80,5 \\
\hline 10. & Power Factor $100 \%$ & 0.83 & 0.77 \\
\hline 11. & Diameter $(\mathrm{mm})$ & 139,5 & 139,5 \\
\hline 12. & Panjang $(\mathrm{m})$ & 634 & 544 \\
\hline 13. & Berat $(\mathrm{kg})$ & 45,5 & 35,5 \\
\hline
\end{tabular}

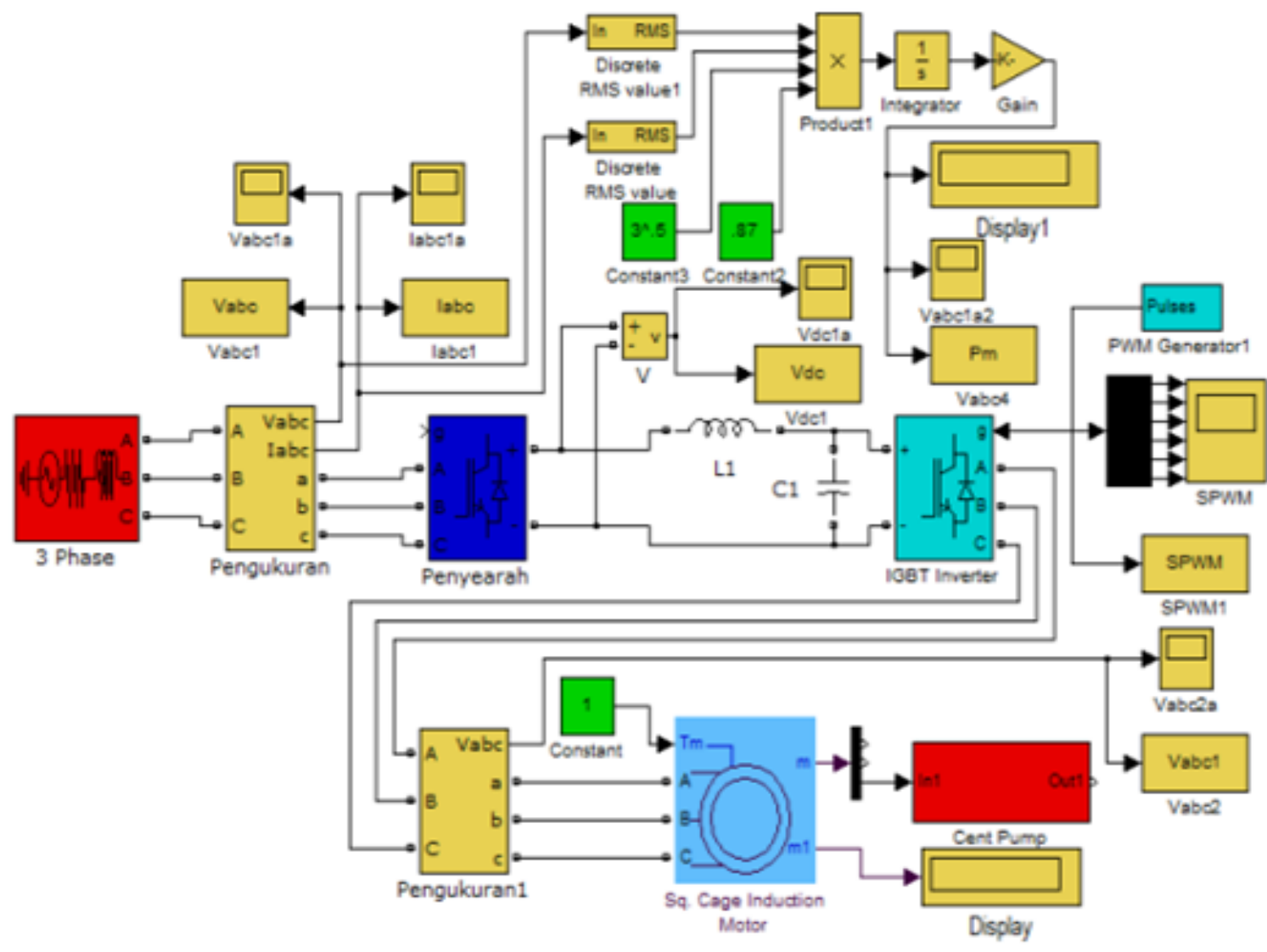

Gambar 2. Desain model simulasi sistem dengan menggunakan variable frequency drive VFD 


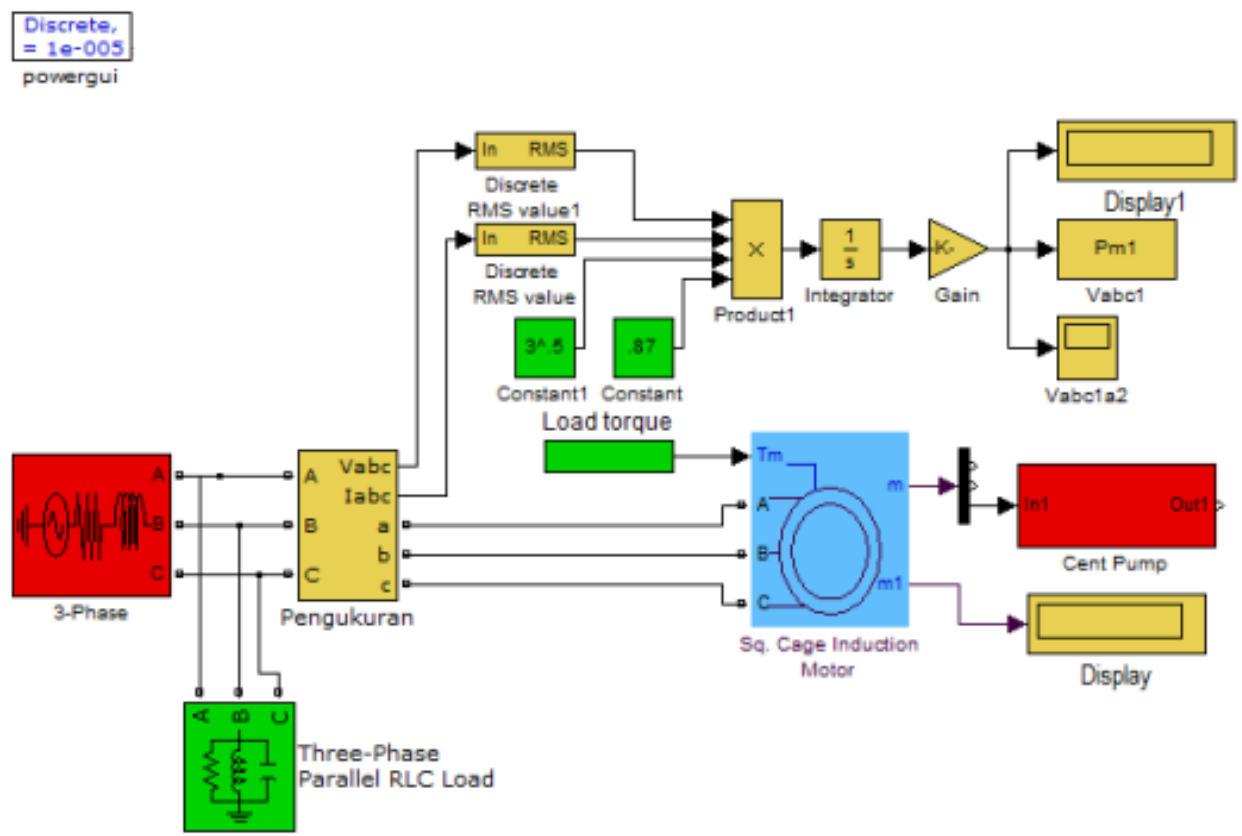

Gambar 3. Desain model simulasi sistem tanpa variable frequency drive (VFD)

\section{Setting Parameter}

Untuk men-setting nilai masing-masing parameter dilakukan dari mulai bagian sumber tegangan sampai ke bagian reservoir pada subsistem pompa sentrifugal. Besar nilainya disesuaikan dengan nilai yang ada pada data yang diperoleh di lapangan dan sebagian lagi mengikuti nilai yang sudah ada pada parameter blok (default).

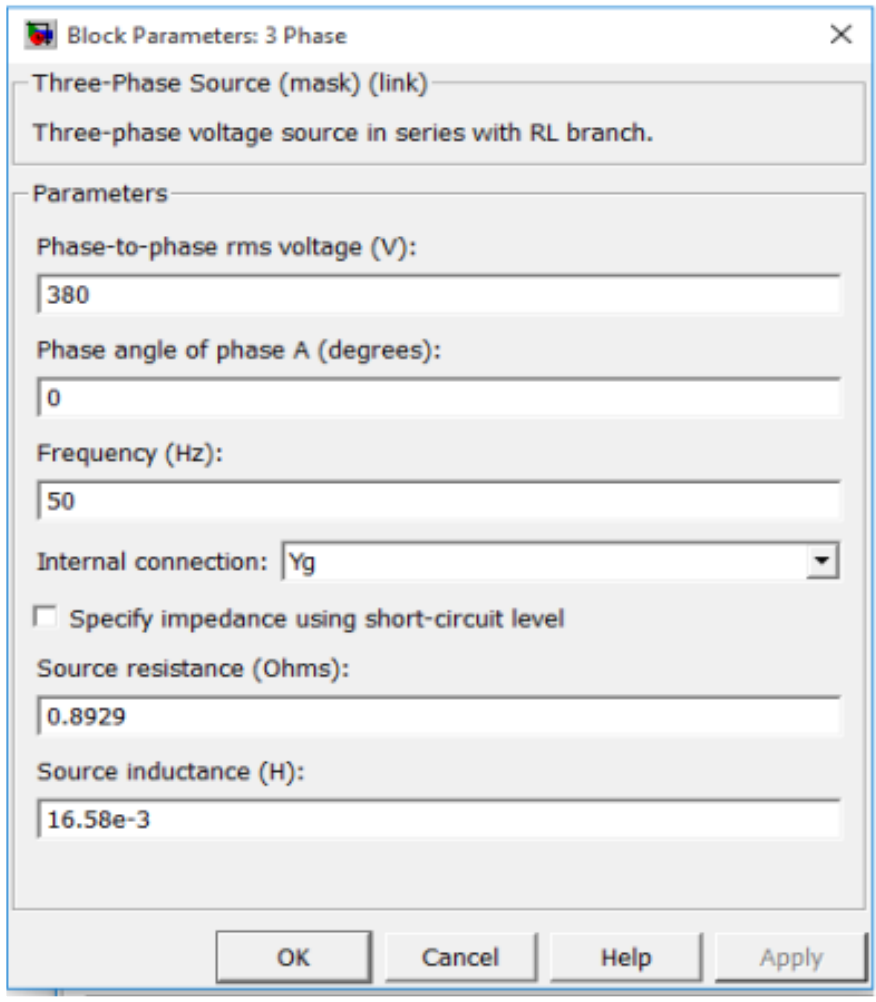

Gambar 4. Parameter blok sumber tegangan 3-phasa 


\section{Hasil Perhitungan}

Untuk hasil perhitungan dan gelombang keluaran ditampilkan dalam bentuk gambar, seperti pada gambar 5 sampai dengan gambar 8. Sedangkan untuk besarnya penghematan energi dihitung secara manual menggunakan persamaan 7 sampai dengan persamaan 12 .

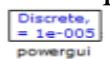

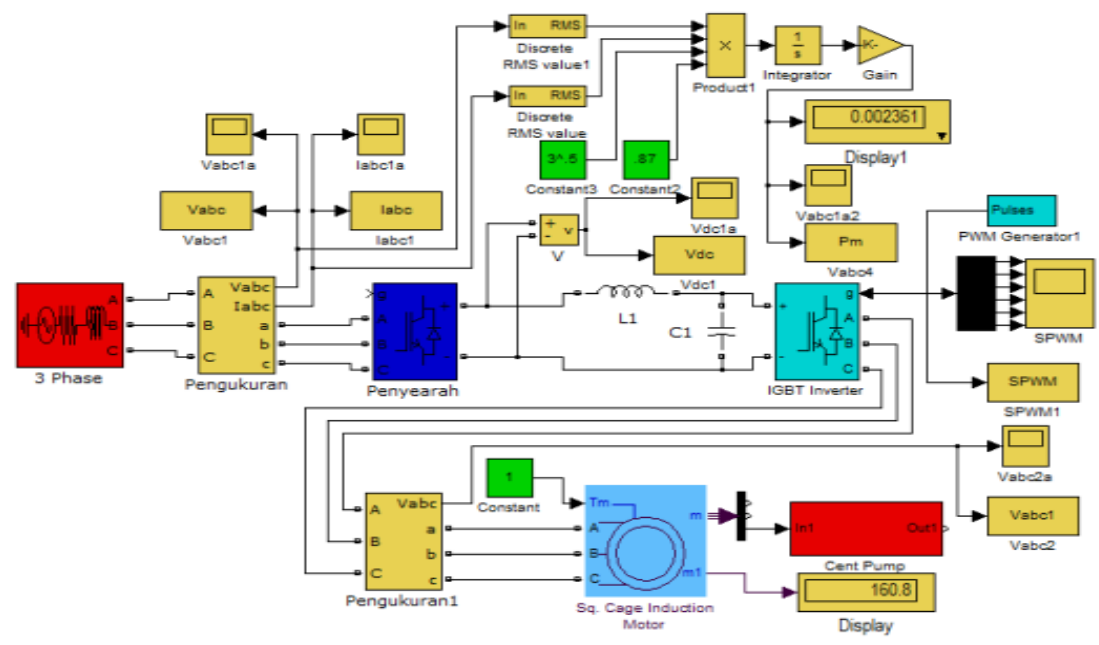

Gambar 5. Hasil perhitungan daya sistem dengan variable frequency drive untuk Pengok 1

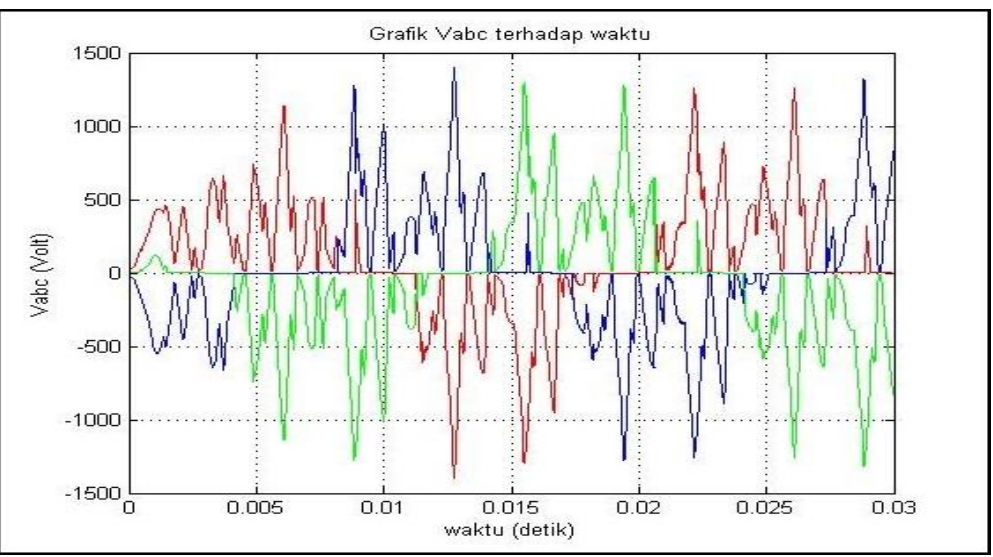

Gambar 6. Bentuk gelombang keluaran tegangan sumber Vabc untuk sistem dengan VFD di Pengok 1

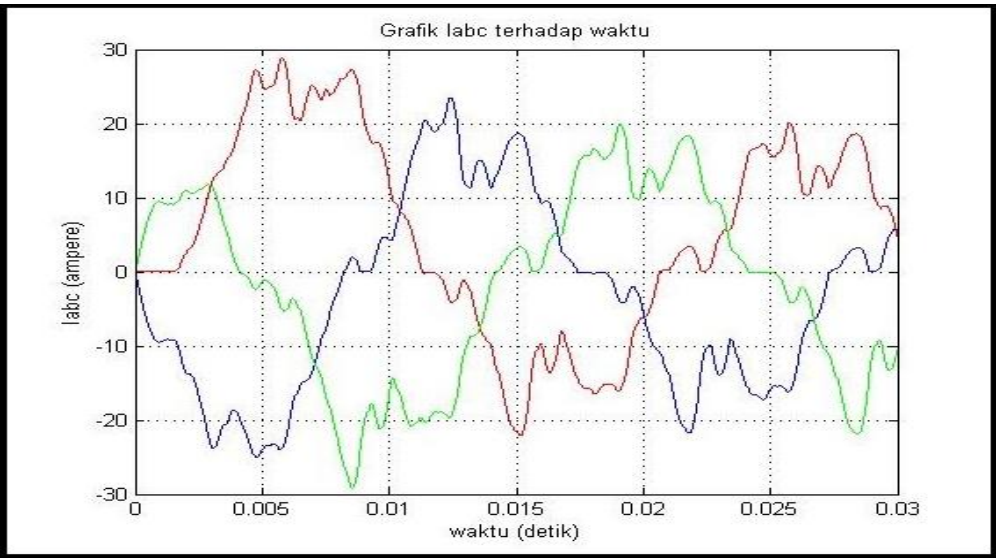

Gambar 7. Bentuk gelombang keluaran arus sumber Iabc untuk sistem dengan VFD di Pengok 1 


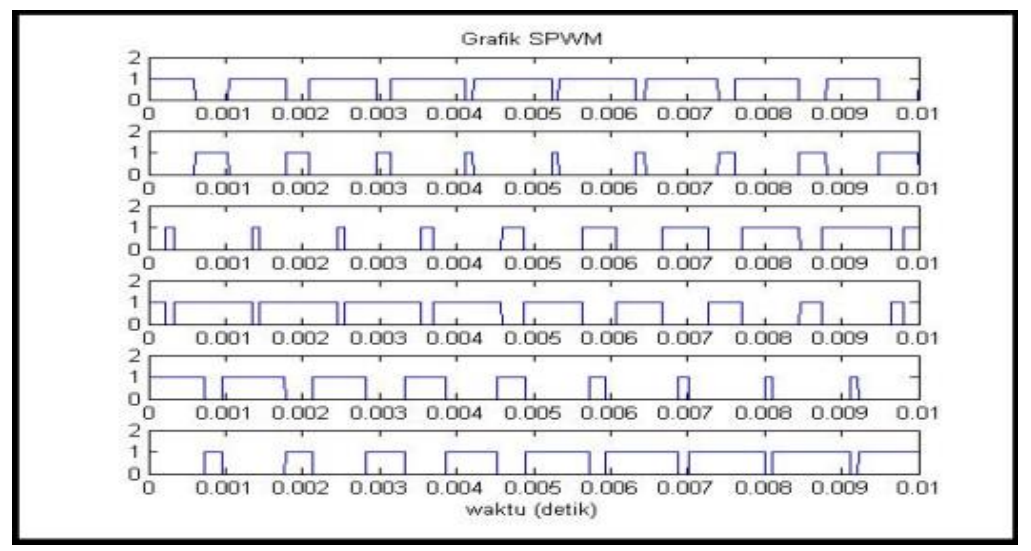

Gambar 7. Bentuk gelombang keluaran SPWM untuk sistem dengan VFD di Pengok 1

Pada gambar 7 memperlihatan bentuk gelombang keluaran SPWM untuk sistem dengan variable frequency drive (VFD). Pulsa-pulsa ini akan digunakan untuk menswitching IGBT. Setiap 1phasa ditangani oleh dua IGBT sehingga setiap 1 phasa memerlukan dua pulsa yang saling bergantian, dimana pergeseran pulsa ditunjukan oleh perbedaan naiknya pulsa yang berbeda-beda.

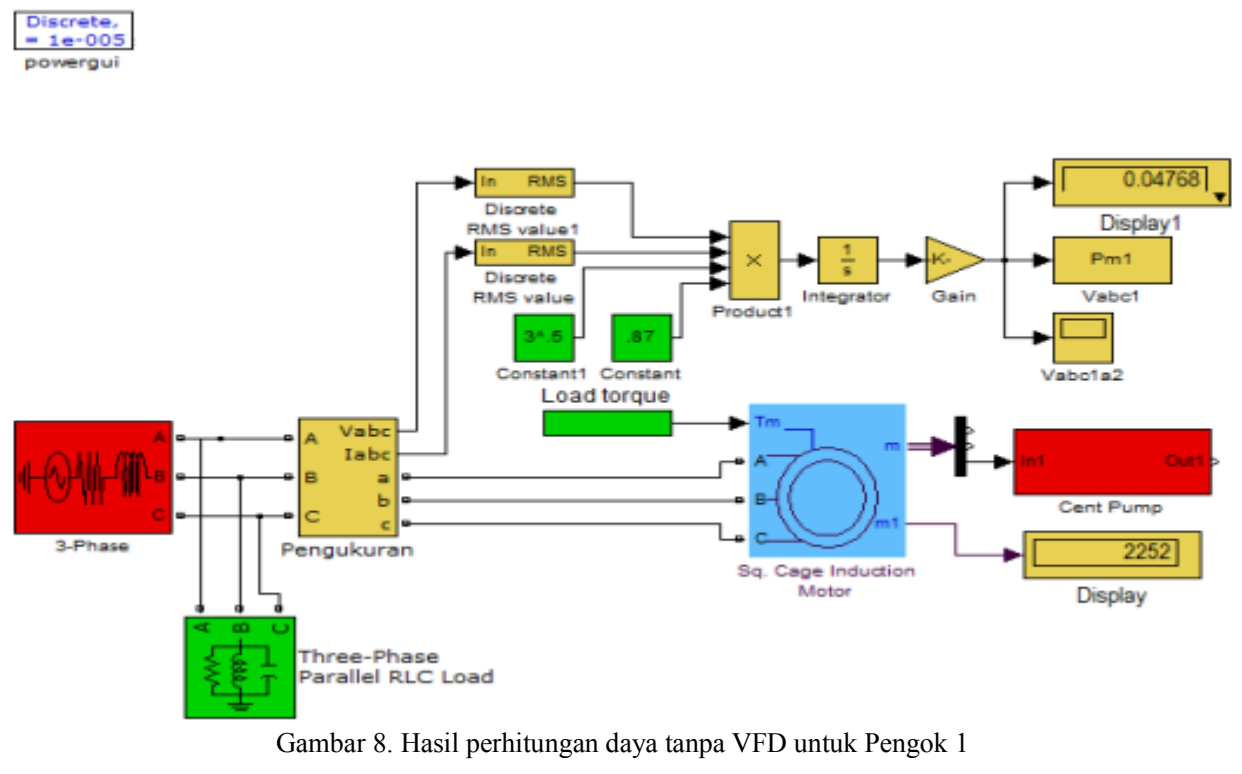

Dari hasil perhitungan, besarnya potensi penghematan pada instalasi pengolahan air (IPA) di Pengok 1 adalah:

- Dengan menggunakan VFD = 0,002361 kWh (diperlihatkan pada display 1 pada gambar 5), dengan menggunakan persamaan 7 berarti konsumsi rata-rata per hari (E1)

$=0,002361 \mathrm{kWh} \times 24=0,056664 \mathrm{kWh}$

- Tanpa VFD = 0, $04768 \mathrm{kWh}$ (diperlihatkan pada display 1 pada gambar 8), dengan menggunakan persamaan 9 berarti konsumsi energi rata-rata per hari $(\mathrm{E} 2)=1,14432 \mathrm{kWh}$

- Penghematan energi per hari $=\mathrm{E} 2-\mathrm{E} 1=1,14432 \mathrm{kWh}-0.056664 \mathrm{kWh} \quad=1,087656 \mathrm{kWh}$

- Penghematan energi pertahun $=365 \times(\mathrm{E} 2-\mathrm{E} 1)=365 \times 1,087656 \mathrm{kWh}=396,99444 \mathrm{kWh}$

Dengan cara yang sama potensi penghematan pada instalasi pengolahan air (IPA) di Pengok 2 adalah:

- Dengan menggunakan VFD $=0,001471 \mathrm{kWh}$, berarti konsumsi energi rata-rata per hari (E1) $=0.001471 \mathrm{kWh} \times 24=0.035304 \mathrm{kWh}$

- Tanpa VFD $=0.03243 \mathrm{kWh}$, berarti konsumsi energi rata-rata per hari (E2) $=0.03243 \mathrm{kWh} \times 24=0.77832 \mathrm{kWh}$

- Penghematan energi per hari $=\mathrm{E} 2-\mathrm{E} 1=0.77832-0.035304 \mathrm{kWh}$ 


\section{$=0.743016 \mathrm{kWh}$}

- Penghematan energi per tahun $=365 \times(\mathrm{E} 2-\mathrm{E} 1)=365 \times 0.743016 \mathrm{kWh}=271,20084 \mathrm{kWh}$

Total penghematan energi per tahun $=396,9944 \mathrm{kWh}+271,20084 \mathrm{kWh}=668,19524 \mathrm{kWh}$

\section{KESIMPULAN}

Validasi model simulasi dilakukan dengan membandingkan bentuk gelombang keluaran model simulasi dengan bentuk gelombang referensi. Validasi model simulasi untuk sistem tanpa variable frequency drive juga dilakukan dengan membandingkan nilai hasil keluaran model simulasi dengan hasil dari perhitungan manual.

Dengan membuat model simulasi variable frequency drive akan dapat diketahui potensi penghematan yang akan diberikan sekiranya variable frequency drive tersebut digunakan di lapangan.

\section{DAFTAR PUSTAKA}

[1] Hanan Nugroho, "Konservasi energi sebagai keharusan yang terlupakan dalam manajemen energi nasional Indonesia: Belajar dari Jepang dan Muangthai," 2005.

[2] Direktorat Konservasi Energi, Direktorat Jenderal Energi Baru Terbarukan dan Konservasi Energi, Kementrian ESDM, "Instrumen kebijakan tentang penghematan energi," Workshop Energy Audit Pilot Project In Industry and Building, Jakarta, 4 Desember 2012.

[3] Jigar N. Mistry, Hetal D. Solanki, and Tejas M. Vala,'Variable frequency drive," International Refereed Research Journal, vol. 2, issue $3,2012$.

[4] Annapurna Birdar and Ravindra G. Patil,'Energy conservation using variable frequency drive,' International Journal of Emerging Trends in Electrical and Electronics (IJETEE), vol. 2, issue 1, April 2013.

[5] Charles M. Burt, Xianshu Piao, Franklin Gaudi, Bryan Busch, and N.F.N. Taufik,'Electric Motor Efficiency under variable frequencies and loads," 2008.

[6] Mr.Priyank Dave, Mr.Kashyap Mokariya, and Mr.Vijay Patel,'Energy conservation in centrifugal pump with vareiable frequency drive including SCADA, PLC, and HMI," International Journal of Innovative Research in Science, Engineering and Technology, vol. 2, issue 5, May 2013.

[7] Thida Win, Nang Sabai and Hnin Nandar Maung,"Analysis of variable frequency three phase induction motor drive," World Academy of Science, Engineering and Technology, 2008.

[8] Michel A. Bernier and Bernard Baurret,"Pumping energy and variable frequency drive," ASHRAE Journal, December 1999.

[9] Keendali PID, 2012. Diakses dari: http://emka.id/special/electro/2012/apa-itu-pengontrol-pid/.

[10] Yusnan Badruzzaman,’Pengasutan konvensional motor induksi tiga fasa rotor sangkar tupai,’Jurnal JTET, vol. 1, no. 1, April 2012.

[11] Zuhal,"Dasar tenaga listrik," Penerbit ITB Bandung, 1991.

[12] Hamad Raad Salih, Ali Abdulwahhab Abdulrazzaq, Basarab, and Guzun,'Dynamic modeling of pump drive system utilizing Simulink/matlab program," International Research Journal of Engineering and Technology (IRJET), vol. 3, issue 1, Jan-2016.

[13] Cekmas Cekdin dan Taufik Barlian,’Rangkaian Listrik," Penerbit Andi Yogyakarta, 2013.

[14] Pedoman Efisiensi Energi untuk Industri,’Pompa dan sistem pemompaan," United Nations Environment Programme (UNEP), 2006. 